\title{
Increased Expression of 14-3-3 $\beta$ Promotes Tumor Progression and Predicts Extrahepatic Metastasis and Worse Survival in Hepatocellular Carcinoma
}

\author{
Tzu-An Liu, ${ }^{*}$ Yee-Jee Jan, ${ }^{\dagger \neq}$ Bor-Sheng Ko, ${ }^{\star}$ \\ Shyh-Chang Chen, ${ }^{\dagger}$ Shu-Man Liang, ${ }^{*}$ \\ Ya-Lin Hung, * Chiun Hsu," Tang-Long Shen," \\ Yen-Ming Lee, ${ }^{* \star \dagger \dagger}$ Pei-Feng Chen, ${ }^{*}$ John Wang, ${ }^{\dagger}$ \\ Song-Kun Shyue, ${ }^{* *}$ and Jun-Yang Liou* \\ From the Institute of Cellular and System Medicine,* National \\ Health Research Institutes, Zhunan; the Department of Pathology \\ and Laboratory Medicine, Taichung Veterans General Hospital, \\ Taichung; the Medical College of Chung Shan Medical \\ University, ${ }^{\ddagger}$ Taichung; the Departments of Internal Medicine ${ }^{\S}$ \\ and Oncology, "National Taiwan University Hospital, Taipei; the \\ Department of Plant Pathology and Microbiology," National Taiwan \\ University, Taipei; the Institute of Biomedical Sciences,** \\ Academia Sinica, Taipei; and the Graduate School of Life \\ Science, ${ }^{+\dagger}$ National Defense Medical Center, Taipei, Taiwan
}

14-3-3 $\beta$ is implicated in cell survival, proliferation, migration, and tumor growth; however, its clinical relevance in tumor progression and metastasis have never been elucidated. To evaluate the clinical significance of 14-3-3 $\beta$, we analyzed the association of 143-3 $\beta$ expression and clinicopathologic characteristics in primary and subsequent metastatic tumors of hepatocellular carcinoma patients. 14-3-3 $\beta$ was expressed abundantly in 40 of $55(\mathbf{7 0 . 7 \% )}$ primary tumors. Increased 14-3-3 $\beta$ expression in primary tumors predicted a higher 5-year cumulative incidence of subsequent extrahepatic metastasis, and multivariate analysis revealed 14-3-3 $\beta$ overexpression was an independent risk factor for extrahepatic metastasis. Patients with increased 14-3-3 $\beta$ expression in primary tumors had worse 5-year overall survival rates, and 14-3-3 $\beta$ overexpression was an independent prognostic factor on Cox regression analysis. Furthermore, stably overexpressed 14-3-3 $\beta$ enhanced hepatocellular carcinoma cell migration and proliferation and increased anchorage-independent cell growth. In addition, in vivo study in a nude-mice model showed tumor formation significantly increased with 14-3-3 $\beta$ overexpression. In conclusion, this is the first report to show that increased 14-3-3 $\beta$ expression is associated with sub- sequent extrahepatic metastasis and worse survival rates, as well as cancer progression of hepatocellular carcinoma. Thus, 14-3-3 $\beta$ may be a novel prognostic biomarker and therapeutic target in hepatocellular carcinoma. (Am J Pathol 2011, 179:2698-2708; DOI: 10.1016/j.ajpath.2011.08.010)

Hepatocellular carcinoma ( $\mathrm{HCC}$ ) is considered a serious public health problem in endemic areas of hepatitis $\mathrm{B}$ or C viral infection, including Africa and Southeast Asia. ${ }^{1}$ Despite recent progress in surgical and nonsurgical treatment, the prognosis for HCC patients still is dismal, in part because a substantial portion of the disease is discovered at an advanced stage when curative therapy is not possible. ${ }^{2}$ Even patients with operable tumors show high rates of local recurrence or distant metastasis. ${ }^{3,4}$ Therefore, investigating accurate prognostic biomarkers to identify patients at high risk of recurrence or metastasis is of utmost importance for developing preventive strategies to improve the outcomes of HCC patients.

14-3-3 proteins are a family of 28- to 33-kDa acidic polypeptides, and their sequences are highly conserved in eukaryotic organisms. ${ }^{5}$ Seven 14-3-3 isoforms $(\beta, \varepsilon, \gamma, \eta, \sigma, \tau / \theta$, and

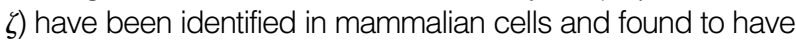
widely diverse intracellular functions. ${ }^{5}$ In general, homodimerization or heterodimerization is required for 14-3-3 proteins to interact with and regulate associated intracellular proteins via phospho-serine/threonine binding activities. ${ }^{6}$ Moreover, 14-3-3 proteins can regulate cell survival, proliferation, motility, and contribute to oncogenesis.,

Supported by the National Science Council (NSC-98-2320-B-400-008MY3), National Health Research Institutes (NHRI-99A1-CSPP08-014), Department of Health (DOH100-TD-C-111-001) and Taichung Veterans General Hospital (TCVGH-1005801B) of Taiwan.

Accepted for publication August 11, 2011

T.A.L., Y.J.J., and B.S.K. contributed equally to this work.

Address reprint requests to Jun-Yang Liou, Ph.D., Institute of Cellular and System Medicine, National Health Research Institutes, Zhunan Town, Miaoli County 350, Taiwan, or Song-Kun Shyue, Ph.D., Institute of Biomedical Sciences, Academia Sinica, Taipei 115, Taiwan. E-mail: jliou@nhri.org.tw or skshyue@ibms.sinica.edu.tw. 
Some studies have shown isoform-specific expression of 14-3-3 proteins associated with various types of human malignancies. For instance, increased $14-3-3 \zeta$ expression promoted anchorage-independent cell growth in lung cancer cell lines, ${ }^{8}$ and expression of $14-3-3 \zeta$ was associated with a worse disease-free survival rate and a high recurrence rate in human breast cancer. ${ }^{9}$ The expression of six 14-3-3 isoforms was found to be increased in human lung cancer tissues. ${ }^{10}$ In addition, $14-3-3 \beta$ and $14-3-3 \eta$ were found specifically expressed in human astrocytoma. ${ }^{11,12}$ The expression frequency and levels of $14-3-3 \beta$ and $14-3-3 \eta$ were associated with human astrocytoma. ${ }^{12}$ Moreover, increased expression of $14-3-3 \varepsilon$ in breast cancer was shown in a proteomic study. ${ }^{13}$ Intriguingly, 14-3-3 $\sigma$ (also known as stratifin) initially was considered a tumor-suppressor gene, and reduced 14-3-3 $\sigma$ expression was reported to increase the probability of metastasis in human nasopharyngeal carcinoma,${ }^{14}$ lung squamous cell carcinoma, ${ }^{15} \mathrm{HCC},{ }^{16}$ and ovarian cancer. ${ }^{17}$ In contrast, an increasing number of studies have indicated that the expression of 14-3-3 $\sigma$ was increased and associated with colorectal cancer myometrial invasion and lymph node metastasis. ${ }^{10,18-21}$ Proteomic profiling analyses have suggested that $14-3-3 \sigma$ is up-regulated in human cirrhosis-type gastric carcinoma cells ${ }^{22}$ and human oral squamous cell carcinoma. ${ }^{23}$ Moreover, a recent study showed that nuclear expression of 14-3-3 $\sigma$ was useful in prediction and was related to prognosis in patients with esophageal squamous cell carcinoma. ${ }^{24}$

Overexpression of $14-3-3 \beta$ in NIH3T3 cells stimulated cell proliferation, anchorage-independent growth, and tumor formation. ${ }^{25}$ This induced oncogenic transformation and cell growth was mediated by mitogen-activated protein kinase (MAPK)-dependent signal activation. ${ }^{25}$ Forced expression of anti-sense 14-3-3 $\beta$ RNAs reduced the growth of rat hepatoma $\mathrm{K} 2$ cells in vivo and in vitro. ${ }^{26}$ Furthermore, up-regulation of 14-3-3 $\beta$ expression was reported to be an effector in Kaposi's sarcoma and papillary thyroid carcinomas in mediating cell proliferation and tumor progression. ${ }^{27,28}$ Increased 14-3-3 $\beta$ expression was observed in human lung cancer tissue, ${ }^{10}$ and the expression of $14-3-3 \beta$ was associated with the aggressiveness of human astrocytoma. ${ }^{12}$ These results provide strong evidence that $14-3-3 \beta$ plays a vital role in tumor growth and progression. However, no convincing clinical study of the association of 14-3-3 $\beta$ expression and tumor metastasis and progression in $\mathrm{HCC}$ has been reported. In this study, we investigated the association of 14-3-3 $\beta$ expression and clinicopathologic characteristics of HCC. We found 14-3-3 $\beta$ overexpression associated with distant metastasis and overall survival of HCC patients. We further performed the in vivo and in vitro experiments to show the role of $14-3-3 \beta$ in HCC cell migration, proliferation, and tumor growth.

\section{Materials and Methods}

\section{Patients and Clinical Specimens}

Tissue samples were obtained from $55 \mathrm{HCC}$ patients who underwent surgery for tumor resection or biopsy in
Taichung Veterans General Hospital and retrospectively were enrolled (from January 1999 to December 2001) in this study. The mean follow-up period was $58.6 \pm 28.6$ months. Eighteen patients (32.7\%) were shown by tissue analysis to develop metastasis 3 to 87 months after the diagnosis and surgery for primary HCC. The metastasis sites included bone (6 patients), abdominal and chest wall (5 patients), brain (2 patients), mesentery (1 patient), gall bladder (1 patient), peritoneum (1 patient), adrenal gland (1 patient), and retroperitoneum (1 patient). The paraffin-embedded surgical specimens composed of the primary and metastatic tumor and surrounding noncancerous liver parenchyma underwent pathology examination. Pathologic features, including Barcelona Clinic Liver Cancer staging, ${ }^{29}$ and clinical outcomes were analyzed. This study was approved by the Institutional Review Board of Taichung Veterans General Hospital.

\section{Immunohistochemical Analysis}

For immunohistochemistry analysis, an automatic immunostaining device and ultraView detection kit (Ventana XT Medical System, Tucson, AZ) was used to detect 14-3-3 $\beta$ expression in paraffin-embedded tissues by use of a primary antibody against 14-3-3 $\beta$ (1:800; Santa Cruz Biotechnology, Santa Cruz, CA). A negative control was prepared by the same staining procedure but not incubated with the primary antibody. The intensity of $14-3-3 \beta$ protein staining was scored semiquantitatively by a Quick-score (Q-score) method based on intensity and heterogeneity. ${ }^{30-34}$ Staining intensity was scored as 0 (negative), 1 (weak), 2 (moderate), or 3 (strong). For heterogeneity, the proportion of tumor cells positively stained with 14-3-3 $\beta$ was scored as follows: $0(0 \%), 1$ ( $1 \%$ to $25 \%$ ), 2 (26\% to $50 \%$ ), 3 ( $51 \%$ to $75 \%$ ), and 4 ( $76 \%$ to $100 \%)$. The Q-score of a given tissue sample was the sum of the intensity and heterogeneity scores and ranged from 0 to 7 . The scoring of each sample was evaluated independently and blindly by 2 pathologists. A Q-score of 2 or greater was considered overexpressed or positive 14-3-3 $\beta$ expression, and a Q-score of less than 2 was considered normal or negative $14-3-3 \beta$ expression. Some rare cases with less than $5 \%$ weakly stained specimens were considered negative expression.

\section{Cell Culture, Stable Cells, and Reagents}

Huh-7 human hepatoma cells were maintained in Dulbecco's modified Eagle's medium (Gibco, Gaithersburg, MD) supplemented with $10 \%$ fetal bovine serum (FBS; Hyclone Thermo Fisher Scientific, Waltham, MA), $100 \mathrm{U} / \mathrm{mL}$ penicillin, and $100 \mathrm{U} / \mathrm{mL}$ streptomycin, in a humidified incubator with $5 \% \mathrm{CO}_{2}$ at $37^{\circ} \mathrm{C}$. For stable transfection, 14-3-3 $\beta$ cDNA was amplified by PCR and then subcloned into the p3XFlag-CMV vector. Huh-7 cells were transfected with p3XFlag-CMV (control) and 14-3-3 $\beta$ cDNA (14-3-3 $\beta$ ) by use of Polyjet transfection reagent (SignaGen Laboratories, ljamsville, MD) according to the manufacturer's instructions. The transfected cells were screened with G418 (500 $\mu \mathrm{g} / \mathrm{mL}$; Biochrom AG, Berlin, Germany) for 4 weeks. Single colonies of stable clones 
(at least 3 in each cell line) were maintained in DMEM with $10 \%$ FBS and $200 \mu \mathrm{g} / \mathrm{mL}$ G418. The established stable cell lines were confirmed by Western blot analysis of Flag expression. The Mek $1 / 2$ inhibitor U0126 was purchased from Sigma-Aldrich (St. Louis, MO).

\section{Western Blot Analysis}

Stable 14-3-3 $\beta$ overexpression and control cells were lysed in ice-cold radioimmunoprecipitation assay buffer ( $0.5 \mathrm{~mol} / \mathrm{L}$ Tris- $\mathrm{HCl}, \mathrm{pH} 7.4,1.5 \mathrm{~mol} / \mathrm{L} \mathrm{NaCl}, 2.5 \%$ deoxycholic acid, 10\% NP-40, 10 mmol/L EDTA; Millipore, Temecula, CA) containing cocktail protease inhibitors (Roche, Indianapolis, IN). Cell lysates were clarified by centrifugation at $16,100 \times g$ for 20 minutes at $4^{\circ} \mathrm{C}$. Protein concentrations were determined by a Bio-Rad protein assay kit (Bio-Rad Laboratories, Hercules, CA). In total, $20 \mu \mathrm{g}$ protein of each sample was applied to a gradient SDS-PAGE gel and immunoblotted onto polyvinylidene difluoride membranes. The membranes were blocked for 1 hour in PBST (phosphate buffered saline with Tween 20, $0.1 \%$ Tween 20, $2.67 \mathrm{mmol} / \mathrm{L} \mathrm{KCl}, 1.47 \mathrm{mmol} / \mathrm{L}$ $\mathrm{KH}_{2} \mathrm{PO}_{4}, 137.93 \mathrm{mmol} / \mathrm{L} \mathrm{NaCl}, 8.1 \mathrm{mmol} / \mathrm{L} \mathrm{Na}{ }_{2} \mathrm{HPO}_{4}, \mathrm{pH}$ 7.4) containing $5 \%$ nonfat dry milk. Membranes were incubated with primary antibodies against Flag (SigmaAldrich), Erk1/2, and phosphorylated-Erk1/2 (Cell Signaling, Danvers, MA) overnight and washed 3 times with PBST for 5 minutes. The membranes were immersed in PBST containing horseradish-peroxidase-conjugated secondary antibody for 1 hour and protein levels were determined by use of enhanced chemiluminescence reagents.

\section{Immunofluorescence Staining}

Stable 14-3-3 $\beta$ overexpression and control cells grown on glass coverslips were fixed in $2 \%$ paraformaldehyde for 15 minutes at $4^{\circ} \mathrm{C}$. After washing, cells were permeabilized with $0.1 \%$ Triton X-100 in PBS for 5 minutes and blocked with PBS containing $10 \%$ FBS at room temperature for 1 hour. Cells were incubated with 14-3-3 $\beta$ antibodies in PBS containing $1 \% \mathrm{FBS}$ at $4^{\circ} \mathrm{C}$ overnight, then incubated with rhodamine-conjugated donkey antimouse secondary antibody in PBS containing $5 \%$ bovine serum albumin at room temperature for 2 hours. Samples were mounted in mounting medium (IBIDI, Martinsried, Germany), and images were analyzed using the Leica TCS SP5 Confocal Imaging System (Leica, Wetzlar, Germany).

\section{Migration Assay}

A Boyden chamber with Bio-coat cell migration chambers was used for cell migration assay (Becton Dickinson, Pont-de-Claix, France) as described previously. ${ }^{35,36}$ Briefly, cells were trypsinized and suspended in $0.1 \%$ bovine serum albumin-DMEM and then $6 \times 10^{4}$ cells were added to the upper wells, which had $8-\mu \mathrm{m}$ pores. Cells were allowed to migrate toward the bottom wells containing $100 \mu \mathrm{g} / \mathrm{mL}$ fibronectin (Becton Dickinson), transforming growth factor $\beta(20 \mathrm{ng} / \mathrm{mL})$, and $10 \%$ bovine serum albumin-DMEM for 20 hours. Cells remaining on the upper side were removed, and migrated cells on the bottom side were fixed and stained with $0.1 \%$ crystal violet containing $20 \%$ ethanol and $1 \%$ formaldehyde for 20 minutes. Cell migration was quantified by counting the total number of migrated cells in 3 inserts.

\section{Cell Proliferation Assay}

Cell proliferation was measured by MTT assay. ${ }^{37,38}$ In brief, 1,500 cells were seeded onto the flat bottom of 96-well plates in $200 \mu \mathrm{L}$ serum-free medium. After cells attached, the medium was replaced with fresh medium containing $10 \%$ FBS for incubation at the indicated times $(0,24,48,74$ hours). MTT was added to each well and incubated at $37^{\circ} \mathrm{C}$ for 3 hours. Subsequently, the yellow MTT solution was removed and the produced formazan was solubilized by adding $200 \mu \mathrm{L}$ dimethyl sulfoxide. Absorbance at $570 \mathrm{~nm}$ was measured with a reference wavelength of $690 \mathrm{~nm}$.

\section{Quantitative Real-Time PCR}

Total RNA was extracted by use of the RNAspin Mini Kit (GE Health Care, Freiburg, Germany). cDNA was synthesized from 2 to $5 \mu \mathrm{g}$ RNA by use of the oligo(dT) primers and RevertAid First Strand cDNA Synthesis Kit (Fermentas Thermo Fisher Scientific, Waltham, MA). Quantitative real-time PCR involved using SYBR Green (Kapabiosystem, Woburn, MA) with specific oligonucleotide primers: E-cadherin, forward: 5'-CGAGAGCTACACGTTCACGG-3', reverse: 5'-GGCCTTTTGACTGTAATCACAML-3'; cyclin A, forward: 5'-TGAACTACATTGATAGGTTCCTGT-3', reverse: 5'-TGACTGTTGTGCATGCTGTGGTGC-3'; cyclin D, forward: 5'-GCCAACCTCCTCAACGACCGG-3', reverse: 5'-GTCCATGTTCTGCTGGGCCTG-3'; cyclin E, forward: 5'-ATAATGCAGTCTGTGCAGAC-3', reverse: 5'-GTTGTGTGCATCTTCATCAG-3'; Snail, forward: 5'-AATCGGAAGCCTAACTACAGCG-3', reverse: 5'-GTCCCAGATGAGCATTGGCA$3^{\prime}$, from the $A B 7900 \mathrm{HT}$ system (Applied Biosystems, Carlsbad, CA). Applied Biosystems Relative Quantification Manager Software version 1.2 was used to analyze the relative gene expression in each sample by the comparative cycle threshold (Ct) method. Gene expression was normalized to that of glyceraldehyde-3-phosphate dehydrogenase.

\section{Anchorage-Independent Growth Assay}

Anchorage-independent growth was assessed by softagar assay. ${ }^{39,40}$ In brief, $5 \times 10^{3}$ cells were seeded onto 6 -well plates with $2 \mathrm{~mL}$ complete DMEM containing $0.8 \%$ low-melting agarose (Lonza, Rockland, ME), then overlaid with $2 \mathrm{~mL}$ complete DMEM containing $0.4 \%$ lowmelting agarose. Cells were overlaid with additional complete medium every 6 days. After 3 weeks, cells were stained with $0.005 \%$ crystal violet in $25 \%$ methanol. Colony numbers were counted and representative images were captured. 


\section{Knockdown of 14-3-3 $\beta$ by siRNA}

Scramble siRNA (sc-37007) and small-interfering RNA (siRNA) targeting 14-3-3 $\beta$ (sc-29186) were purchased from Santa Cruz Biotechnology. For siRNA transfection experiments, 14-3-3 $\beta$ overexpressed and control cells were dissociated into single cells in suspension and plated on 6-well plates. Cells were transfected with scramble and $14-3-3 \beta$ siRNA according to the manufacturer's protocol. Briefly, 14-3-3 $\beta$ and scramble siRNAs (30 pmol) were diluted in $500 \mu \mathrm{L}$ DMEM and mixed with $5 \mu \mathrm{L}$ Lipofectamine RNAiMAX (Invitrogen, Carlsbad, CA). After 15 minutes' incubation at room temperature, the complexes were added to the cells with a final volume of $3 \mathrm{~mL}$ medium. Cells were harvested at the indicated time for further analysis. The efficiency of the 14-3-3 $\beta$ siRNA was confirmed by Western blot analysis of Flag expression.

\section{Tumor Xenograft Experiments}

BALB/c nu/nu nude mice (8 weeks old) were purchased from the National Laboratory Animal Center (National Science Council, Taiwan), and housed in microisolator cages at a specific pathogen-free facility. Control and 14-3-3 $\beta$ stable cells were trypsinized, washed, and resuspended in PBS. A total of $2 \times 10^{6}$ cells in $0.3 \mathrm{~mL}$ PBS were injected subcutaneously into the right flank of nude mice. ${ }^{41,42}$ Tumor development was followed up in individual animals twice a week. Tumor volume was determined by sequential caliper measurements of length $(L)$ and width $(\mathrm{W})$ and calculated as $\mathrm{LW}^{2} / 2$. Mice were sacrificed at day 35 , tumors were removed, and tumor weight was measured. The protocol of the in vivo experiments was approved by the Institutional Animal Care and Utilization Committee of Academia Sinica.

\section{Statistical Analysis}

One-way analysis of variance was used to analyze differences among clinicopathologic variables by 143-3 $\beta$ expression. Factors that influence extrahepatic metastasis were analyzed by multivariate logistic regression. The Wilcoxon signed-rank test was used to analyze the differences between primary tumors and matched metastatic tissues by $14-3-3 \beta$ staining density. Kaplan-Meier curves were plotted, and the logrank test was used to analyze time-related probabilities of metastasis, overall survival, and progression-free survival, and to calculate $P$ value. Cox proportional hazard regression models were used to evaluate the impact of prognostic factors on survival. The Student's $t$-test was used to analyze differences among 2 groups. A $P$ value of $<0.05$ was considered statistically significant, and a $P$ value between 0.05 and 0.10 was considered marginally significant.
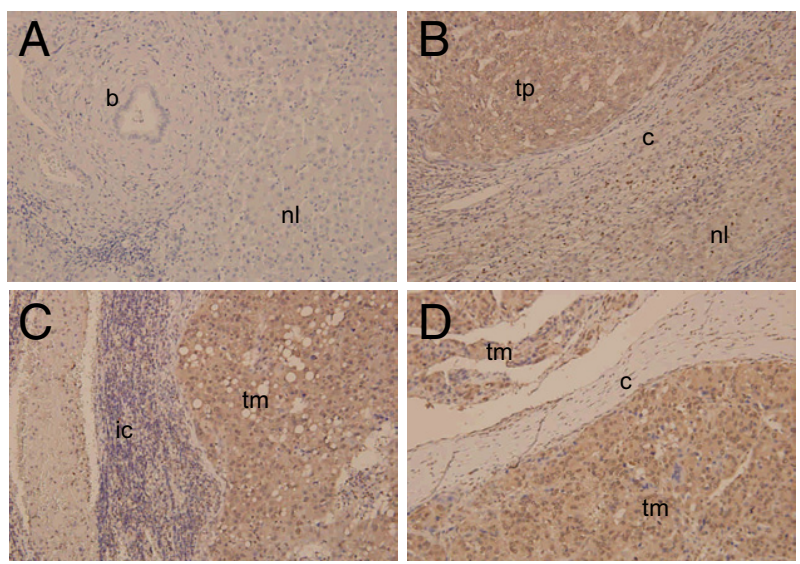

Figure 1. Immunohistochemical analysis of $14-3-3 \beta$ in primary and metastatic HCC tissues. A: Negative control staining. Original magnification, $\times 200$. B: $14-3-3 \beta$ staining in representative primary HCC. Original magnification, $\times 200$. Tumor cells were stained positively. C: Positive staining of $14-3-3 \beta$ in representative metastatic HCC lesions in lung gallbladder (D). Original magnification, $\times 200$. b, bile duct; c, capsule; ic, inflammatory cells; nl, normal liver; tm, metastatic tumors; tp, primary tumors.

\section{Results \\ Overexpression of 14-3-3 $\beta$ in Primary and Metastatic HCC Tissues}

To examine the expression of $14-3-3 \beta$ in HCC, paraffinembedded primary HCC tumors with surrounding noncancerous parenchyma from 55 patients and 18 matched extrahepatic metastatic tumors underwent immunohistochemical staining. 14-3-3 $\beta$ was not detectable or stained with background in noncancerous liver tissues (data not shown), and negative control slides were stained negatively (Figure 1A). The expression of 14-3-3 $\beta$ was increased in $40(72.7 \%)$ of 55 primary HCC tumors, and noncancerous cells adjacent to tumors were stained negatively (Figure 1B and Table 1). Moreover, 14-3-3 $\beta$ was overexpressed in 18 matched metastatic HCC specimens, as illustrated representatively in a metastatic lesion in the lung (Figure 1C) and gall bladder (Figure 1D). Overexpression of $14-3-3 \beta$ was not related significantly to most clinicopathologic characteristics but was associated, although weakly, with advanced Barcelona Clinic Liver Cancer stage $(P=0.076)$, tumor size $(P=0.081)$, presence of microvascular thrombi $(P=0.058)$, and high $\alpha$-fetoprotein level $(P=0.098)$ (Table 1).

\section{Association of 14-3-3 $\beta$ Overexpression and Extrahepatic Metastasis in HCC}

Overexpression of $14-3-3 \beta$ in primary HCC tumors was associated significantly with subsequent extrahepatic metastasis $(P=0.002)$ (Table 1$)$. On multivariate analysis, overexpression of $14-3-3 \beta$ was the only factor predicting distant $\mathrm{HCC}$ metastasis $(P<0.001)$ (Table 2). The cumulative probability of developing extrahepatic metastasis within 5 years was significantly higher in primary HCC with positive versus negative 14-3-3 $\beta$ expression $(39.9 \% \pm 7.9 \%$ versus $0.0 \% ; P=0.008)$ (Figure 2$)$. 
Table 1. Correlation of $14-3-3 \beta$ Positivity with Clinicopathologic Characteristics in Primary Tumors of HCC Patients.

\begin{tabular}{|c|c|c|}
\hline Parameters & $\begin{array}{c}14-3-3 \beta \text { positivity } \\
(\mathrm{Q}-\text { score } \geq 2) \% \\
(n)\end{array}$ & $P$ value \\
\hline Overall $(n=55)$ & $72.7 \%(40)$ & \\
\hline Age & & NS \\
\hline$\geq 60$ years $(n=28)$ & $71.4 \%(20)$ & \\
\hline$<60$ years $(n=27)$ & $74.1 \%(20)$ & \\
\hline Sex & & NS \\
\hline Male $(n=39)$ & $71.8 \%(28)$ & \\
\hline Female $(n=16)$ & $75.0 \%(12)$ & \\
\hline Histologic grade & & NS \\
\hline $1(n=4)$ & $50.0 \%(2)$ & \\
\hline $2(n=42)$ & $73.8 \%(31)$ & \\
\hline $3(n=9)$ & $77.8 \%(7)$ & \\
\hline Types of surgery & & NS \\
\hline Core biopsy $(n=3)$ & $100.0 \%(3)$ & \\
\hline Wedge resection $(n=18)$ & $55.6 \%(10)$ & \\
\hline Segmentectomy $(n=28)$ & $75.0 \%(21)$ & \\
\hline Lobectomy $(n=6)$ & $100.0 \%(6)$ & \\
\hline Surgical margin & & NS \\
\hline Not available $(n=3)$ & $100.0 \%(3)$ & \\
\hline Free $(n=41)$ & $70.7 \%(29)$ & \\
\hline Involved $(n=11)$ & $72.7 \%(8)$ & \\
\hline BCLC staging & & 0.076 \\
\hline Not available $(n=3)$ & & \\
\hline $\begin{array}{l}\text { Early (stage } A 1 \text { to } A 4) \\
\quad(n=29)\end{array}$ & $65.5 \%(19)$ & \\
\hline $\begin{array}{l}\text { Intermediate (stage B) } \\
\quad(n=21)\end{array}$ & $90.5 \%(19)$ & \\
\hline $\begin{array}{l}\text { Advanced (stage C) } \\
\quad(n=2)\end{array}$ & $100.0 \%(2)$ & \\
\hline Tumor size & & 0.081 \\
\hline Not available $(n=2)$ & $100.0 \%(2)$ & \\
\hline$\geq 5.0 \mathrm{~cm}(n=12)$ & $91.7 \%(11)$ & \\
\hline$<5.0 \mathrm{~cm}(n=41)$ & $65.9 \%(27)$ & \\
\hline Tumor multiplicity & & NS \\
\hline Not available $(n=1)$ & $100.0 \%(1)$ & \\
\hline Single $(n=42)$ & $69.0 \%(29)$ & \\
\hline Multiple $(n=12)$ & $83.3 \%(10)$ & \\
\hline Capsular formation & & NS \\
\hline Not available $(n=11)$ & $72.7 \%(8)$ & \\
\hline Yes $(n=23)$ & $78.3 \%(18)$ & \\
\hline No $(n=21)$ & $66.7 \%(14)$ & \\
\hline Vascular thrombi & & 0.058 \\
\hline Not available $(n=3)$ & $100.0 \%(3)$ & \\
\hline Yes $(n=17)$ & $88.2 \%(15)$ & \\
\hline No $(n=35)$ & $62.9 \%(22)$ & \\
\hline Cirrhosis & & NS \\
\hline Not available $(n=6)$ & $66.7 \%(4)$ & \\
\hline Yes $(n=33)$ & $72.7 \%(24)$ & \\
\hline No $(n=16)$ & $75.0 \%(12)$ & \\
\hline Viral hepatitis & & NS \\
\hline Not available $(n=4)$ & $50.0 \%(2)$ & \\
\hline Hepatitis B $(n=28)$ & $75.0 \%(21)$ & \\
\hline Hepatitis C $(n=17)$ & $70.1 \%(12)$ & \\
\hline Both $(n=5)$ & $80.0 \%(4)$ & \\
\hline None $(n=1)$ & $100.0 \%(1)$ & \\
\hline$\alpha$-Fetoprotein level & & 0.098 \\
\hline Not available $(n=7)$ & $42.9 \%(3)$ & \\
\hline$\geq 80 \mathrm{ng} / \mathrm{mL}(n=19)$ & $89.5 \%(17)$ & \\
\hline$<80 \mathrm{ng} / \mathrm{mL}(n=29)$ & $69.0 \%(20)$ & \\
\hline $\begin{array}{l}\text { Subsequent extrahepatic } \\
\text { metastasis }\end{array}$ & & $0.002^{*}$ \\
\hline Yes $(n=18)$ & $100.0 \%(18)$ & \\
\hline No $(n=37)$ & $59.4 \%(22)$ & \\
\hline
\end{tabular}

${ }^{\star} P<0.05$

BCLC, Barcelona Clinic Liver Cancer; NS, not significant; SD, standard deviation.
Table 2. Multivariate Analysis for Distant Metastasis in HCC Patients

\begin{tabular}{lc}
\hline \multicolumn{1}{c}{ Variables } & $P$ value \\
\hline Histology grade $(1+2: 3)$ & $N S$ \\
Presence of cirrhosis (no: yes) & $N S$ \\
14-3-3 $\beta$ expression (negative: positive) & $<0.001^{\star}$ \\
Bulky tumor $(\geq 5.0 \mathrm{~cm}:<5.0 \mathrm{~cm})$ & 0.095 \\
Surgical margin (free: involved) & $\mathrm{NS}$ \\
Capsular formation (no: yes) & $\mathrm{NS}$ \\
Vascular thrombi (no: yes) & $\mathrm{NS}$ \\
BCLC staging (stage A: B to C) & $\mathrm{NS}$ \\
\hline
\end{tabular}

${ }^{*} P<0.05$.

BCLC, Barcelona Clinic Liver Cancer; NS, not significant

Furthermore, the expression of 14-3-3 $\beta$ was increased significantly in metastatic HCC samples versus their primary tumors (11 with increased Q-score $>2,1$ decreased, and 6 with no difference in $\mathrm{Q}$-score; $P=0.004$ ). These observations suggest a strong correlation of 143-3 $\beta$ expression with extrahepatic metastasis of HCC.

\section{Association of 14-3-3 $\beta$ Overexpression with Patient Survival}

After a mean follow-up period of $58.6 \pm 28.6$ months, 19 patients (34.5\%) remained free of HCC, 21 patients $(38.2 \%)$ had died of their disease, and 15 patients (27.3\%) were still alive with disease recurrence and/or distant metastasis. Survival analysis revealed a significantly better overall survival rate in patients with negative versus positive 14-3-3 $\beta$ expression in primary HCC tumors $(61.5 \% \pm 7.8 \%$ versus $78.6 \% \pm 11.0 \%$ for 5 -year survival; $P=0.046$ ) (Figure 3). However, the increased expression of $14-3-3 \beta$ in primary tumors had no significant effect on progression-free survival in these HCC patients (data not shown). Furthermore, Cox proportionalhazard regression models revealed that overexpression of $14-3-3 \beta$ significantly compromised the probability of overall survival with a hazard ratio of 3.135 (95\% confidence interval, 1.103 to $9.804 ; P=0.043$ ) but had no

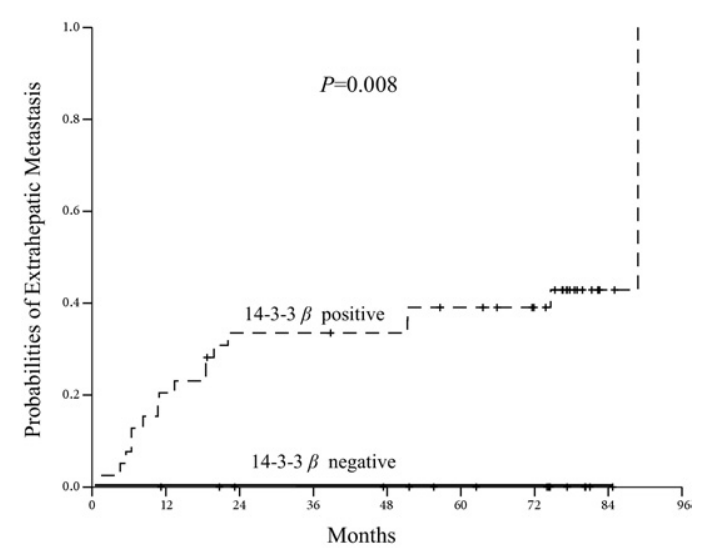

Figure 2. Kaplan-Meier analysis of $14-3-3 \beta$ expression with metastatic risk of HCC patients. The 5-year cumulative probabilities of metastasis for 14-3$3 \beta$-negative patients was significantly lower than for $14-3-3 \beta$-positive patients $(39.9 \% \pm 7.9 \% ; P=0.008)$. 


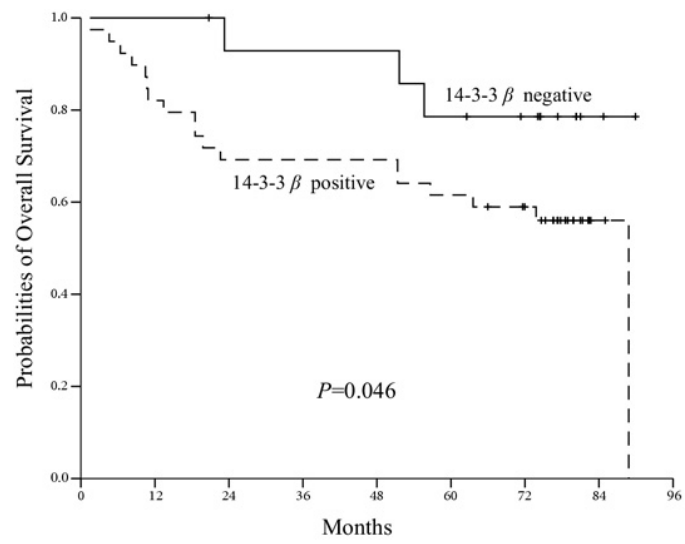

Figure 3. Kaplan-Meier analysis of $14-3-3 \beta$ expression with overall survival of HCC patients. Patients with $14-3-3 \beta$ positivity in primary tissues had a significantly worse 5-year overall survival rate than negative-stained tissues $(61.5 \% \pm 7.8 \%$ versus $78.6 \% \pm 11.0 \% ; P=0.046)$.

effect on progression-free survival (Table 3). These results suggest that overexpression of $14-3-3 \beta$ in primary tumors is an important predicting parameter of worse overall survival of HCC patients.

\section{Regulation of Cell Migration and Proliferation by 14-3-3 $\beta$ Overexpression in HCC}

To explore the effect of $14-3-3 \beta$ on cancer cell migration, proliferation, and tumor progression, we established a stable HCC cell line with 14-3-3 $\beta$ overexpression. Huh-7 cells, determined to express a lower protein level of 14-3-3 $\beta$ (data not shown), were transfected with p3XFlag-CMV (control) and p3XFlag-14-3-3 $\beta$ (14-3-3 $\beta$ ) vectors and selected by G418 for 4 weeks. Protein expression was validated by Western blot analysis of Flag in cells from 14-3-3 $\beta$-Flag stably overexpressed clones (Figure $4 \mathrm{~A}$ ). Clone 1 of control cells and 14-3-3 $\beta$ stable cells were used for most further experiments, and the expression and the subcellular localization of $14-3-3 \beta$ was confirmed by immunofluorescent confocal microscopy (Figure 4B). Expression of $14-3-3 \beta$ was increased significantly and the majority of $14-3-3 \beta$ protein was localized to the cytoplasm but partially to the cytoplasmic membrane or nucleus (Figure 4B). In addition, overexpression of $14-3-3 \beta$ (stable clones 1 to 3 ) significantly induced cell migration in Boyden chamber experiments (Figure 4C).

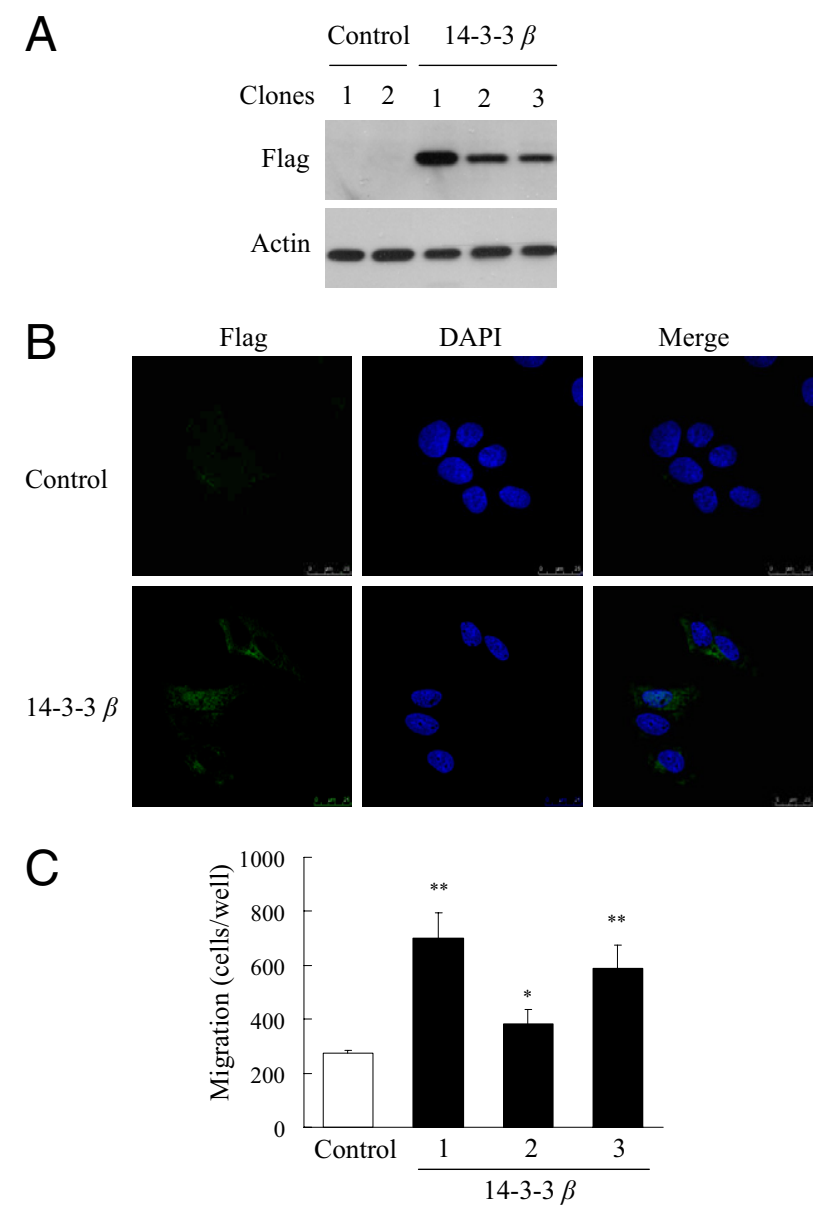

Figure 4. Overexpression of $14-3-3 \beta$ increases HCC cell migration. A: Overexpression of $14-3-3 \beta$ in stable HCC cells confirmed by Western blot analysis. Control, stable cell clones of empty vector (p3XFlag); 14-3-3 $\beta$, stable clones of p3XFlag-14-3-3 $\beta$. B: Overexpression of $14-3-3 \beta$ and its subcellular localization examined by immunofluorescent confocal microscopy. Nuclei were stained with DAPI. Scale bar $=25 \mathrm{um}$. C: Cell migration ability was determined by Boyden chamber assay. Scale bars: mean $\pm \mathrm{SD} .{ }^{*} P<0.05,{ }^{* * *} P<0.01,14-3-3 \beta$ versus control.

To investigate whether 14-3-3 $\beta$ plays an important role in cancer cell proliferation, we determined the mRNA levels of several cell-cycle regulatory factors and found the expression of cyclin $A$, cyclin $D$, and cyclin $E$ were increased significantly in 14-3-3 $\beta$-overexpressed cells (stable clones 1 to 3; Figure 5A). 14-3-3 $\beta$ overexpression inducing $\mathrm{HCC}$ cell proliferation was confirmed further by MTT assay (Figure 5B). Moreover, we determined an-

Table 3. Cox Proportional Hazard Regression Analysis for Survival in HCC Patients

\begin{tabular}{|c|c|c|c|c|}
\hline \multirow[b]{2}{*}{ Variables } & \multicolumn{2}{|c|}{ Overall survival } & \multicolumn{2}{|c|}{ Progression-free survival } \\
\hline & Hazard ratio $(95 \% \mathrm{Cl})$ & $P$ value & Hazard ratio (95\% Cl) & $P$ value \\
\hline 14-3-3 $\beta$ expression (positive: negative) & 3.135 (1.103 to 9.804$)$ & $0.043^{*}$ & $1.838(0.311$ to 10.870$)$ & 0.502 \\
\hline Types of surgery (wedge: wider resection) & $1.232(0.230$ to 6.613$)$ & 0.807 & 0.950 (0.130 to 6.952$)$ & 0.959 \\
\hline Surgical margin (free: involved) & $0.704(0.191$ to 2.599$)$ & 0.598 & $0.686(0.179$ to 2.621$)$ & 0.686 \\
\hline Capsular formation (no: yes) & $0.883(0.313$ to 2.490$)$ & 0.814 & $0.522(0.144$ to 1.894$)$ & 0.522 \\
\hline$\alpha$-Fetoprotein level (low: high) & $0.322(0.108$ to 0.962$)$ & $0.049^{*}$ & $0.301(0.086$ to 1.056$)$ & 0.061 \\
\hline Cirrhosis (no: yes) & $0.563(0.205$ to 1.547$)$ & 0.266 & $0.336(0.079$ to 1.433$)$ & 0.140 \\
\hline BCLC stage (A: B and C) & $1.247(0.447$ to 3.301$)$ & 0.656 & 1.309 (0.355 to 4.823$)$ & 0.686 \\
\hline
\end{tabular}

${ }^{*} P<0.05$.

BCLC, Barcelona Clinic Liver Cancer; Cl, confidence interval; SE, standard error. 
A

Cyclin A

Cyclin D
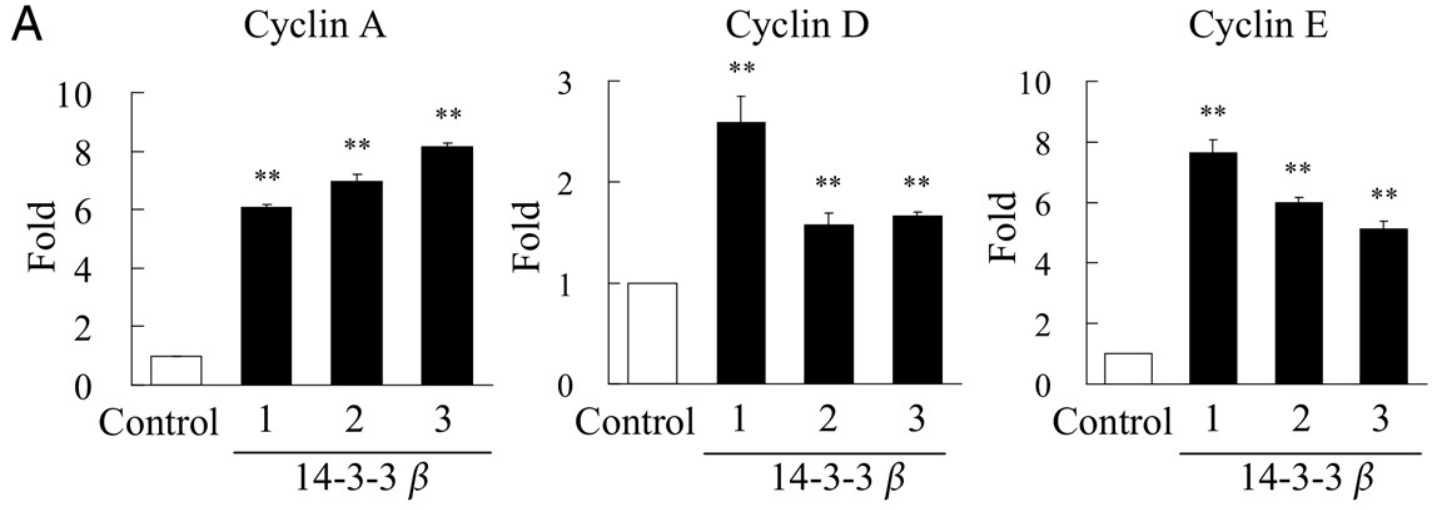

B
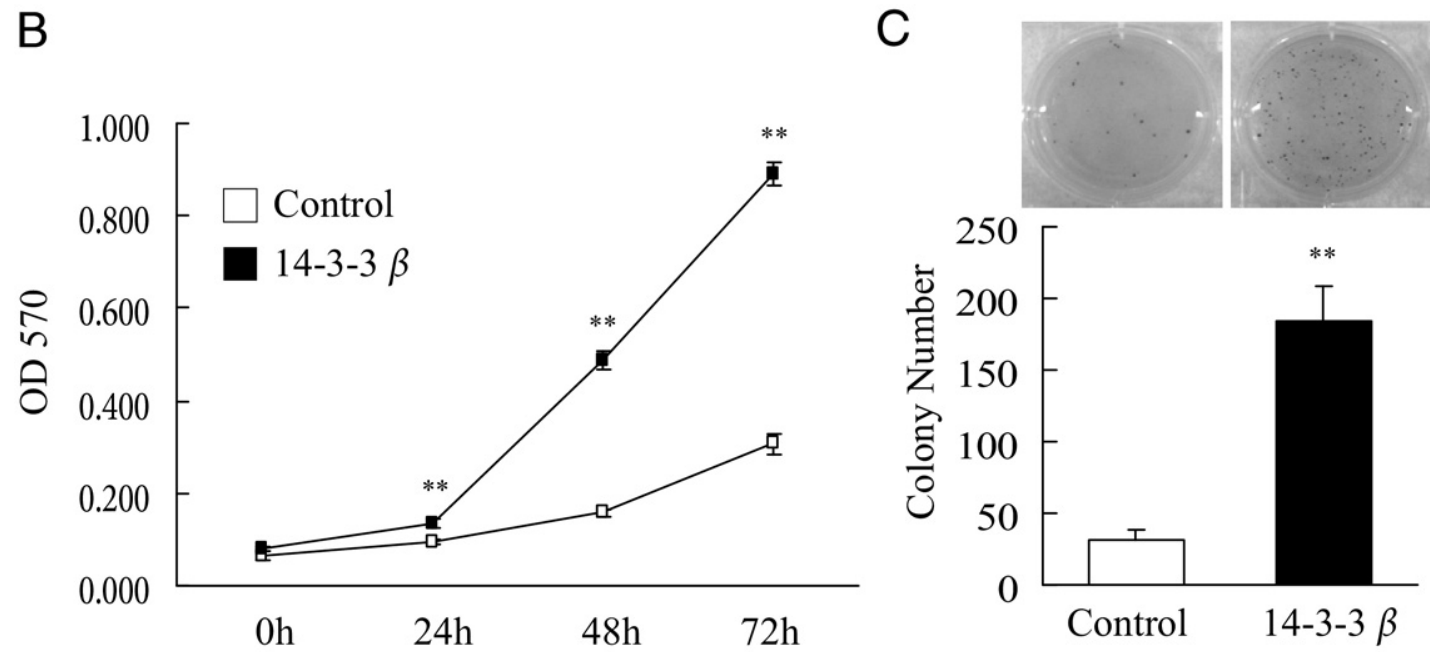

Figure 5. Overexpression of $14-3-3 \beta$ promotes cell proliferation. A: Expression of cyclin A, cyclin D, and cyclin E in control and $14-3-3 \beta$ stable cells determined by quantitative real-time PCR. B: Cell proliferation determined by MTT assay. C: Anchorage-independent growth was determined by soft-agar assay. Representative photographs are shown (upper panel). Quantitative analysis of total colony number in each culture well from 3 separate experiments (bottom panel). Scale bars: mean $\pm \mathrm{SD}$. ${ }^{* *} P<0.01,14-3-3 \beta 1$ versus control.

chorage-independent growth with 14-3-3 $\beta$ overexpression by soft-agar assay. 14-3-3 $\beta$-overexpressed cells significantly increased the colony numbers formed in the soft agar as compared with control cells (Figure $5 \mathrm{C})$. These results suggest that $14-3-3 \beta$ induces HCC cell proliferation and promotes anchorage-independent growth.

To further confirm the role of $14-3-3 \beta$ on HCC cell proliferation and migration, we performed the knockdown experiments by using siRNA. Control and 14-3-3 $\beta$-overexpressed cells were transfected with scramble or 143-3 $\beta$ siRNAs and expression of $14-3-3 \beta$ was determined by Western blot analysis. 14-3-3 $\beta$ siRNA significantly reduced the expression level of Flag-tagged 14-3-3 $\beta$ (Figure 6A). 14-3-3 $\beta$ siRNA suppressed HCC cell proliferation and cell migration was confirmed by MTT assay (Figure 6B) and Boyden chamber experiments (Figure $6 \mathrm{C})$, respectively.

\section{Effect of MAPK on 14-3-3 $\beta$-Induced HCC Cell Proliferation and Migration}

To investigate whether activation of MAPK was involved in 14-3-3 $\beta$-induced HCC cell proliferation and migration, we pretreated cells with U0126, a Mek1/2 inhibitor, and determined the expression level of Erk1/2 phosphorylation by Western blot analysis. Phosphorylated Erk1/2 was enhanced significantly in 14-3-3 $\beta$ overexpressed HCC cells (Figure 7A). U0126 completely abrogated phosphorylation of Erk1/2 in both control and 14-3-3 $\beta$ cells (Figure 7A). We next determined the effect of U0126 on 14-3-3 $\beta$-induced HCC cell growth and migration by MTT and Boyden chamber assays. The increased effects of cell proliferation and migration by $14-3-3 \beta$ were abolished significantly by $\mathrm{U} 0126$ (Figure $7, \mathrm{~B}$ and $\mathrm{C}$ ). These results suggest that $14-3-3 \beta$ promotes HCC progression through activation of a MAPK signal pathway.

\section{Effect of 14-3-3 $\beta$ Overexpression on in Vivo Tumor Growth}

The in vivo xenograft model was used to test the effect of $14-3-3 \beta$ on HCC tumor growth. Control and 14-3-3 $\beta$ overexpressed Huh-7 cells were injected into nude mice for 5 weeks, and tumor volumes and tumor weights were determined. Tumors sizes were significantly larger in nude mice with 14-3-3 $\beta$ overexpression than in control 
A
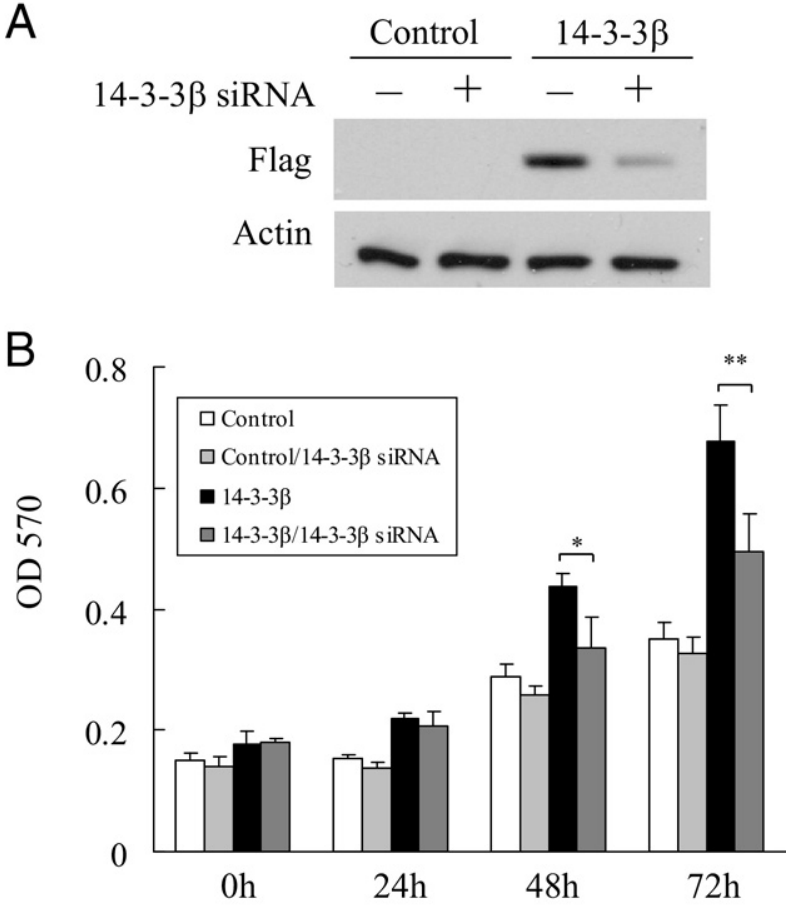

C

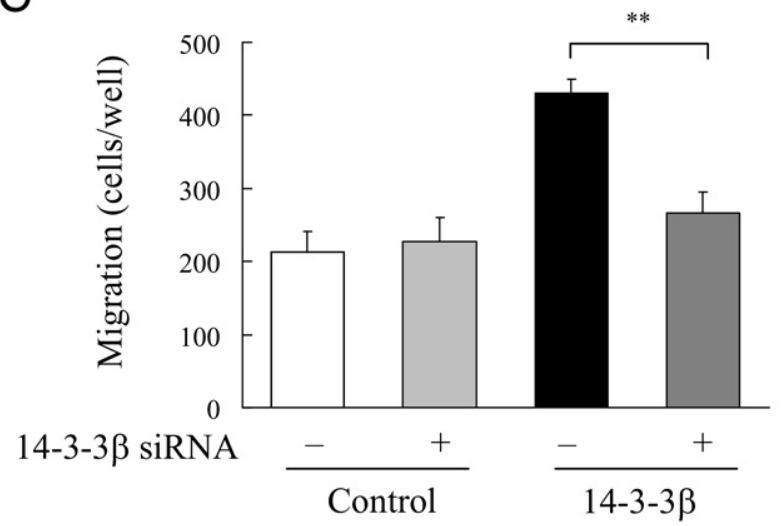

Figure 6. Knockdown 14-3-3 $\beta$ expression by siRNA abolishes $14-3-3 \beta$ induced cell proliferation and migration. A: $14-3-3 \beta$ siRNA reduced $14-3-3 \beta$ expression was determined by Western blot analysis of Flag. Cells were transfected by scramble or $14-3-3 \beta$ siRNA for 48 hours. B: $14-3-3 \beta$ siRNA abrogated $14-3-3 \beta$-induced HCC cell proliferation was determined by MTT assay. C: Cell transfected with scramble or $14-3-3 \beta$ siRNA for 48 hours and migration ability was determined by Boyden chamber assay. Scale bars: mean $\pm \mathrm{SD} .{ }^{*} P<0.05,{ }^{* * *} P<0.01$

mice (Figure 8A). 14-3-3 $\beta$ overexpression significantly increased tumor volume (Figure $8 \mathrm{~B}$ ) and tumor weight as compared with control cells (Figure $8 \mathrm{C}$ ). These results suggest that increased 14-3-3 $\beta$ expression promotes in vivo $\mathrm{HCC}$ tumor growth.

\section{Discussion}

14-3-3 $\beta$ has been implicated in cell survival, proliferation, migration, and tumor growth, but its clinical relevance in terms of tumor progression and metastasis has never been elucidated. In this study, we provide strong clinical evidence that increased $14-3-3 \beta$ expression is related significantly to subsequent extrahepatic metastasis and overall survival in HCC patients. Notably, none of the patients with negative 14-3-3 $\beta$ expression in primary HCC tissues has shown distant metastasis. On multivariate analysis, 14-3-3 $\beta$ overexpression was an independent predicting factor of HCC metastasis. Furthermore, significantly increased $14-3-3 \beta$ expression in metastatic HCC tissues implied a potential biological role in the development of distal metastatic lesions. Thus, 14-3-3 $\beta$ may be a critical regulator of HCC metastasis. In addition, increased 14-3-3 $\beta$ expression in primary tissues was associated significantly with poor overall survival of HCC patients. Interestingly, overexpression of $14-3-3 \beta$ was not associated significantly with other clinicopathologic variables in $\mathrm{HCC}$, which suggests that $14-3-3 \beta$ may not contribute to early HCC carcinogenesis but may have an

A
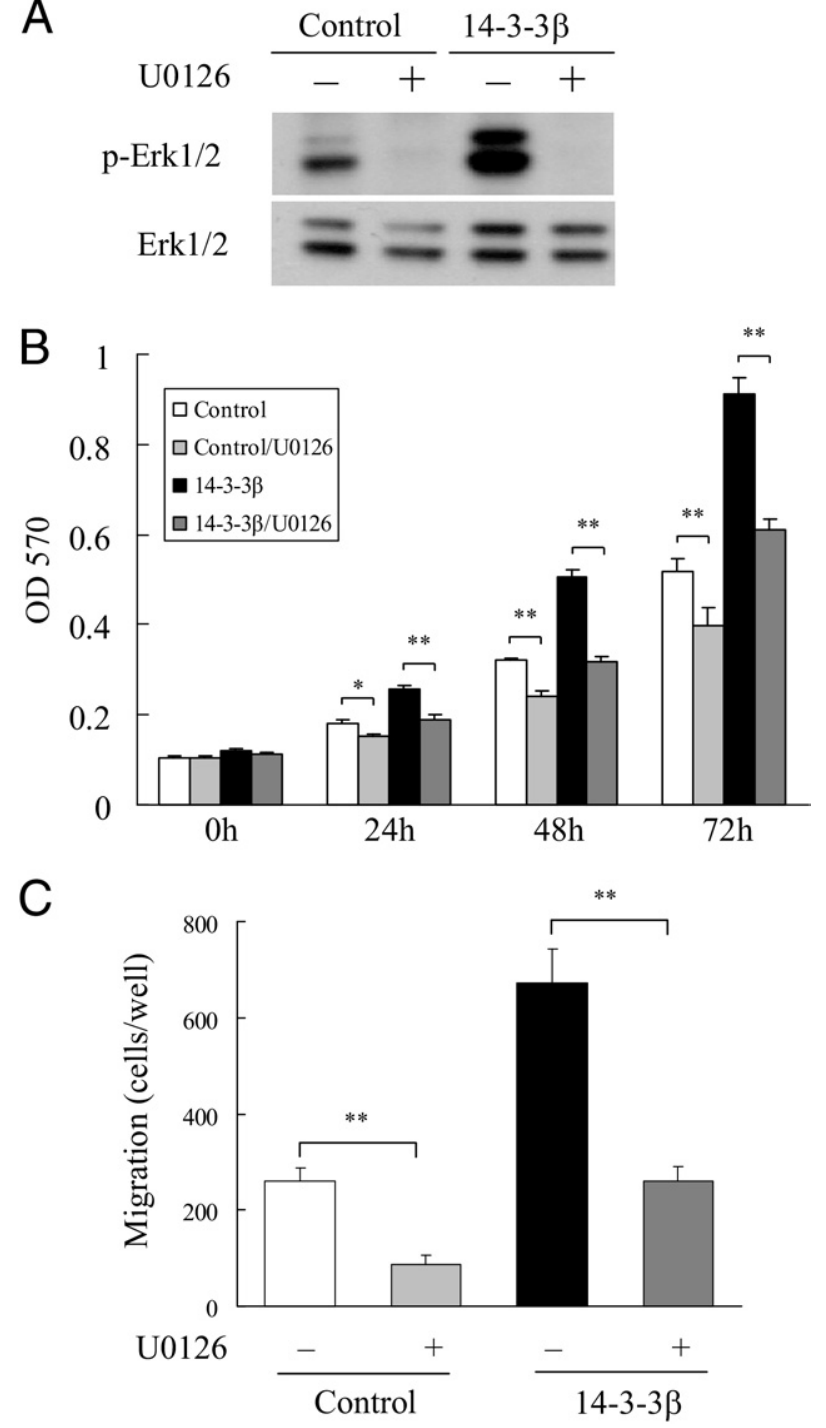

Figure 7. Effect of MAPK on 14-3-3 $\beta$-induced cell proliferation and migration. A: Control and 14-3-3 $\beta$-overexpressed cells were treated with 10 $\mu \mathrm{mol} / \mathrm{L} \mathrm{U} 0126$ for 1 hour. Expression of Erk1/2 and phosphorylated-Erk1/2 were determined by Western blot analysis. B: U0126 abrogated 14-3-3 $\beta-$ induced cell proliferation was determined by MTT assay. C: U0126 suppressed cell migration was determined by Boyden chamber assay. Scale bars: mean $\pm \mathrm{SD} \cdot{ }^{*} P<0.05,{ }^{* * *} P<0.01$. 
A

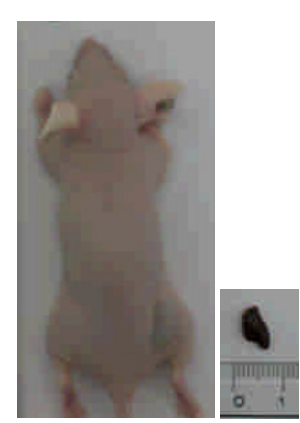

Control

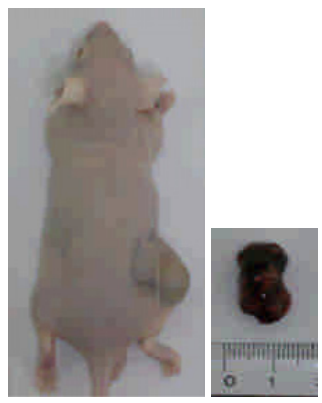

$14-3-3 \beta$
$\mathrm{B}$

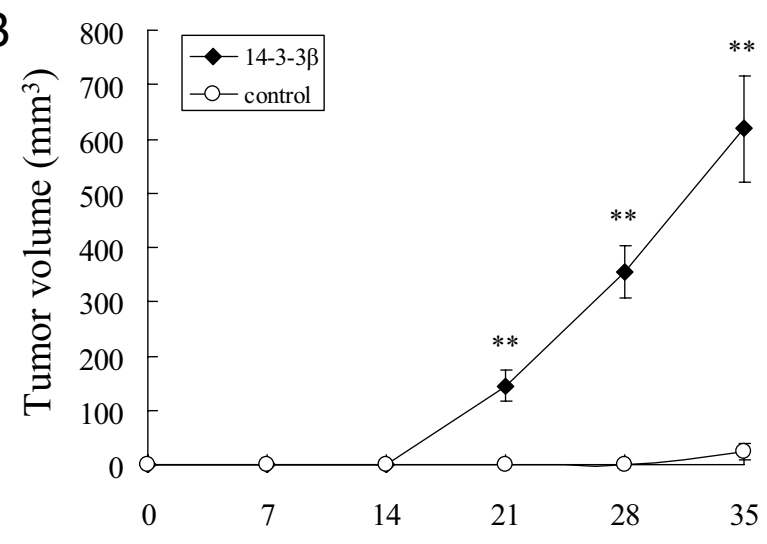

C

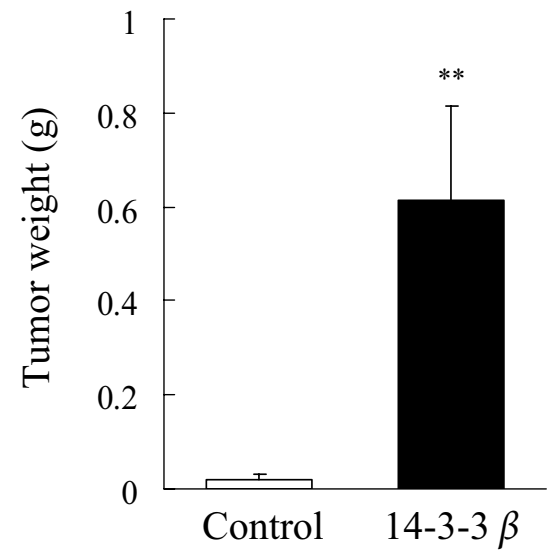

Figure 8. Overexpression of $14-3-3 \beta$ promotes in vino tumor growth. A: Representative photographs of nude mice and developed tumors injected with control (left panel) and 14-3-3 $\beta$ overexpressed (right panel) stable cells at day 35 . Overexpression of $14-3-3 \beta$ significantly increased in vivo tumor growth according to the results of calculated tumor volume (B) and tumor weight $(\mathbf{C})$. Scale bars: mean \pm SEM. ${ }^{* *} P<0.01$

important role in promoting advanced tumor progression, especially metastasis. In support of these data, our in vitro and in vivo xenograft studies provide additional evidence that $14-3-3 \beta$ is tightly involved in the advanced development of HCC. Forced overexpression of $14-3-3 \beta$ induced HCC cell migration and increased cell proliferation, as well as tumor growth. Thus, $14-3-3 \beta$ may be a potential biomarker for distant metastasis and poor survival with $\mathrm{HCC}$.

Our recent studies discovered that the expression of 14-3-3 $\varepsilon$ and $14-3-3 \gamma$ also was increased in a substantial portion of HCC tissues and was associated with distant metastasis and overall survival. ${ }^{33,34}$ These results, along with the dimerization property of 14-3-3 proteins, suggests that $14-3-3 \beta, 14-3-3 \varepsilon$, and $14-3-3 \gamma$ potentially form heterodimers to interact with and regulate their broadspectrum downstream signal effectors in HCC tissues. These 14-3-3 isoforms may express and work synergistically to promote HCC cell migration/invasion, proliferation, and tumor metastasis. Our findings provide a better understanding of the isoform-specific expression profile of 14-3-3 proteins in distinct tumor tissues. Further work is ongoing to investigate the synergism of 14-3-3 isoforms and their mechanistic interacting factors to control advanced $\mathrm{HCC}$ metastasis and progression.

14-3-3 $\beta$ has been shown to bind with phosphorylated Raf- 1 and to activate Raf- 1 kinase activity. ${ }^{43,44}$ Thus, 14-3-3 $\beta$ may contribute to control cell proliferation and differentiation by regulating Raf-1 and its downstream signal pathway factors. An earlier study showed that overexpression of 14-3-3 $\beta$ promotes cell proliferation and oncogenic transformation. ${ }^{25}$ Forced $14-3-3 \beta$ overexpression induced MAPK activity and stimulated NIH3T3 cell growth, anchorage-independent growth, and tumor formation in nude mice. ${ }^{25}$ These induced effects of cell proliferation could be abolished by expression of a dominant-negative mutant of MEK $1 .{ }^{25}$ In addition, a novel $14-3-3 \beta$-interacting protein, $14-3-3 \beta$ interactant 1 (FBI1), was identified by yeast two-hybrid screening. ${ }^{45} 14-3-3 \beta$ bound to and formed a complex with FBI1 and transcriptionally suppressed the expression of MAPK phosphatase-1. ${ }^{45} 14-3-3 \beta$ was thus considered a transcriptional repressor to promote tumorigenicity and metastasis. ${ }^{45}$ Moreover, 14-3-3 $\beta$ was reported to regulate the mammalian target of rapamycin pathway by interacting with and suppressing the activity of the tumor-suppressor tuberous sclerosis complex 2.46,47 Interaction and sequestration of the tuberous sclerosis complex 2 by $14-3-3 \beta$ reduced the binding activity of tuberous sclerosis complex 2 with the mammalian target of rapamycin complex, thereby enhancing mammalian target of rapamycin activity and its subsequent signal pathways to control cell proliferation. These results provide insight into the molecular mechanisms of $14-3-3 \beta$ controlling cell signaling to enhance cancer cell growth.

14-3-3 $\beta$ deregulation was suggested to be associated negatively with tumor growth, ${ }^{26}$ and our current work shows that 14-3-3 $\beta$ overexpression promotes HCC cell growth and migration. However, the clinical significance of 14-3-3 $\beta$ expression with HCC tumor metastasis has never been shown. 14-3-3 $\beta$ was found to be associated with the integrin $\beta 1$ cytoplasmic domain during the early stage of cell migration, and overexpressed 14-3-3 $\beta$ enhanced cell spreading and migration of NIH3T3 cells. ${ }^{48}$ Results from a further study suggested that $14-3-3 \beta$ regulated cell spreading and migration requires a functional amphipathic groove. ${ }^{49}$ In addition, our earlier study revealed focal adhesion kinase, a regulator of nonreceptor tyrosine kinase to control cell adhesion and migration, was overexpressed in HCC tumors. ${ }^{32}$ Thus, $14-3-3 \beta$ may combine with integrin $\beta 1$ and focal adhesion kinase to form a complex to induce HCC cell migration and tumor metastasis. Moreover, $14-3-3 \beta$ stimulated 
Ras-related $\mathrm{C} 3$ botulinum toxin substrate 1 (Rac1)p21-activated kinase signaling to regulate Akt-mediated cytoskeletal organization, lamellipodia formation, and fibronectin matrix assembly. ${ }^{50}$ Taken together, these results have revealed an important role of 14 $3-3 \beta$ in controlling cell migration/invasion and metastasis by affecting integrins or cytoskeletal-regulated signaling pathways.

14-3-3 proteins, including 14-3-3 $\beta$, exert antiapoptotic activity by binding with the proapoptotic Bad protein. ${ }^{6,51-54}$ 14-3-3 proteins interacts with phosphorylated $\mathrm{Bad}$, sequesters Bad in the cytosol, and prevents its mitochondrial translocation, thereby suppressing the mitochondria-mediated apoptosis pathway. ${ }^{6,51-54}$ Furthermore, $14-3-3 \beta$ was reported to be the binding partner of serine/arginine protein-specific kinase $2 .{ }^{55} \quad 14-3-3 \beta$ bound to Akt-phosphorylated serine/arginine proteinspecific kinase 2 to protect it against nuclear translocation, protein degradation, and apoptotic cell death. ${ }^{55}$ Moreover, Akt-mediated phosphorylation was found to trigger 14-3-3 $\beta$-dependent re-localization of S-phase kinase-associated protein 2 to the cytosol to contribute to tumorigenesis. $^{56}$

In conclusion, our study provides strong clinical evidence that $14-3-3 \beta$ is an important and independent factor predicting subsequent distant metastasis and worse survival for patients with operable HCC. Our results imply that $14-3-3 \beta$ is involved in advanced disease progression in HCC. Therefore, $14-3-3 \beta$ may be a potential biomarker to identify HCC patients at high risk of metastasis. New therapeutic strategies or drugs aimed at $14-3-3 \beta$ or other 14-3-3 isoforms and potential targets might be developed for these patients.

\section{Acknowledgment}

We thank the Comprehensive Cancer Center of Taichung Veterans General Hospital for providing information concerning the outcomes of these patients.

\section{References}

1. Sherman M: Hepatocellular carcinoma: epidemiology, surveillance, and diagnosis. Semin Liver Dis 2010, 30:3-16

2. Rampone B, Schiavone B, Martino A, Viviano C, Confuorto G: Current management strategy of hepatocellular carcinoma. World J Gastroenterol 2009, 15:3210-3216

3. Natsuizaka M, Omura T, Akaike T, Kuwata $Y$, Yamazaki K, Sato T, Karino Y, Toyota J, Suga T, Asaka M: Clinical features of hepatocellular carcinoma with extrahepatic metastases. J Gastroenterol Hepatol 2005, 20:1781-1787

4. Hasegawa K, Kokudo N: Surgical treatment of hepatocellular carcinoma. Surg Today 2009, 39:833-843

5. Aitken A: 14-3-3 proteins: a historic overview. Semin Cancer Bio 2006, 16:162-172

6. Morrison DK: The 14-3-3 proteins: integrators of diverse signaling cues that impact cell fate and cancer development. Trends Cell Bio 2009, 19:16-23

7. Tzivion G, Gupta VS, Kaplun L, Balan V: 14-3-3 proteins as potential oncogenes. Semin Cancer Biol 2006, 16:203-213

8. Li Z, Zhao J, Du Y, Park HR, Sun SY, Bernal-Mizrachi L, Aitken A, Khuri FR, Fu H: Down-regulation of 14-3-3zeta suppresses anchorageindependent growth of lung cancer cells through anoikis activation. Proc Natl Acad Sci U S A 2008, 105:162-167
9. Neal CL, Yao J, Yang W, Zhou X, Nguyen NT, Lu J, Danes CG, Guo H, Lan KH, Ensor J, Hittelman W. Hung MC, Yu D: 14-3-3zeta overexpression defines high risk for breast cancer recurrence and promotes cancer cell survival. Cancer Res 2009, 69:3425-3432

10. Qi W, Liu X, Qiao D, Martinez JD: Isoform-specific expression of 14-3-3 proteins in human lung cancer tissues. Int J Cancer 2005 113:359-363

11. Liang S, Shen G, Liu Q, Xu Y, Zhou L, Xiao S, Xu Z, Gong F, You C, Wei $Y$ : Isoform-specific expression and characterization of 14-3-3 proteins in human glioma tissues discovered by stable isotope labeling with amino acids in cell culture-based proteomic analysis. Proteomics Clin Appl 2009, 3:743-753

12. Yang $X$, Cao W, Lin H, Zhang W, Lin W, Cao L, Zhen H, Huo J, Zhang $X$ : Isoform-specific expression of 14-3-3 proteins in human astrocytoma. J Neurol Sci 2009, 276:54-59

13. Li DQ, Wang L, Fei F, Hou YF, Luo JM, Zeng R, Wu J, Lu JS, Di GH, Ou ZL, Xia QC, Shen ZZ, Shao ZM: Identification of breast cancer metastasis-associated proteins in an isogenic tumor metastasis model using two-dimensional gel electrophoresis and liquid chromatography-ion trap-mass spectrometry. Proteomics 2006, 6:33523368

14. Yi B, Tan SX, Tang CE, Huang WG, Cheng AL, Li C, Zhang PF, Li MY, Li JL, Yi H, Peng F, Chen ZC, Xiao ZQ: Inactivation of 14-3-3 sigma by promoter methylation correlates with metastasis in nasopharyngeal carcinoma. J Cell Biochem 2009, 106:858-866

15. Li DJ, Deng G, Xiao ZQ, Yao HX, Li C, Peng F, Li MY, Zhang PF, Chen $\mathrm{YH}$, Chen ZC: Identificating 14-3-3 sigma as a lymph node metastasis-related protein in human lung squamous carcinoma. Cancer Lett 2009, 279:65-73

16. Iwata N, Yamamoto H, Sasaki S, Itoh F, Suzuki H, Kikuchi T, Kaneto H, Iku S, Ozeki I, Karino Y, Satoh T, Toyota J, Satoh M, Endo T, Imai $\mathrm{K}$ : Frequent hypermethylation of $\mathrm{CpG}$ islands and loss of expression of the 14-3-3 sigma gene in human hepatocellular carcinoma. Oncogene 2000, 19:5298-5302

17. Akahira J, Sugihashi $Y$, Suzuki T, Ito K, Niikura H, Moriya T, Nitta M, Okamura H, Inoue S, Sasano H, Okamura K, Yaegashi N: Decreased expression of 14-3-3 sigma is associated with advanced disease in human epithelial ovarian cancer: its correlation with aberrant DNA methylation. Clin Cancer Res 2004, 10:2687-2693

18. Guweidhi A, Kleeff J, Giese N, El Fitori J, Ketterer K, Giese T, Buchler MW, Korc M, Friess H: Enhanced expression of 14-3-3sigma in pancreatic cancer and its role in cell cycle regulation and apoptosis. Carcinogenesis 2004, 25:1575-1585

19. Nakayama H, Sano T, Motegi A, Oyama T, Nakajima T: Increasing 14-3-3 sigma expression with declining estrogen receptor alpha and estrogen-responsive finger protein expression defines malignant progression of endometrial carcinoma. Pathol Int 2005, 55:707-715

20. Neupane D, Korc M: 14-3-3sigma Modulates pancreatic cancer cell survival and invasiveness. Clin Cancer Res 2008, 14:7614-7623

21. Tanaka K, Hatada T, Kobayashi M, Mohri Y, Tonouchi H, Miki C, Nobori T, Kusunoki M: The clinical implication of 14-3-3 sigma expression in primary gastrointestinal malignancy. Int J Oncol 2004, 25:1591-1597

22. Kuramitsu $Y$, Baron B, Yoshino S, Zhang X, Tanaka T, Yashiro M, Hirakawa K, Oka M, Nakamura K: Proteomic differential display analysis shows up-regulation of 14-3-3 sigma protein in human scirrhoustype gastric carcinoma cells. Anticancer Res 2010, 30:4459-4465

23. Hayashi E, Kuramitsu Y, Fujimoto M, Zhang X, Tanaka T, Uchida K, Fukuda T, Furumoto $\mathrm{H}$, Ueyama $\mathrm{Y}$, Nakamura K: Proteomic profiling of differential display analysis for human oral squamous cell carcinoma: 14-3-3 sigma protein is upregulated in human oral squamous cell carcinoma and dependent on the differentiation level. Proteomics Clin Appl 2009, 3:1338-1347

24. Okumura H, Kita Y, Yokomakura N, Uchikado Y, Setoyama T, Sakurai H, Omoto I, Matsumoto M, Owaki T, Ishigami S, Natsugoe S: Nuclear expression of 14-3-3 sigma is related to prognosis in patients with esophageal squamous cell carcinoma. Anticancer Res 2010, 30 5175-5179

25. Takihara $Y$, Matsuda $Y$, Hara J: Role of the beta isoform of 14-3-3 proteins in cellular proliferation and oncogenic transformation. Carcinogenesis 2000, 21:2073-2077

26. Sugiyama A, Miyagi $\mathrm{Y}$, Komiya $\mathrm{Y}$, Kurabe N, Kitanaka $\mathrm{C}$, Kato $\mathrm{N}$, Nagashima $Y$, Kuchino $Y$, Tashiro F: Forced expression of antisense 
14-3-3beta RNA suppresses tumor cell growth in vitro and in vivo. Carcinogenesis 2003, 24:1549-1559

27. Musholt TJ, Brehm C, Hanack J, von Wasielewski R, Musholt PB: Identification of differentially expressed genes in papillary thyroid carcinomas with and without rearrangements of the tyrosine kinase receptors RET and/or NTRK1. J Surg Res 2006, 131:15-25

28. Zeng Y, Li Y, Chen RS, He X, Yang L, Li W: Overexpression of XCT induces up-regulation of 14-3-3beta in Kaposi's sarcoma. Biosci Rep 2010, 30:277-283

29. Llovet JM, Bru C, Bruix J: Prognosis of hepatocellular carcinoma: the BCLC staging classification. Semin Liver Dis 1999, 19:329-338

30. Barnes DM, Harris WH, Smith P, Millis RR, Rubens RD: Immunohistochemical determination of oestrogen receptor: comparison of different methods of assessment of staining and correlation with clinical outcome of breast cancer patients. Br J Cancer 1996, 74:1445-1451

31. Chang GC, Liu KJ, Hsieh CL, Hu TS, Charoenfuprasert S, Liu HK, Luh KT, Hsu LH, Wu CW, Ting CC, Chen CY, Chen KC, Yang TY, Chou TY, Wang WH, Whang-Peng J, Shih NY: Identification of alpha-enolase as an autoantigen in lung cancer: its overexpression is associated with clinical outcomes. Clin Cancer Res 2006, 12:5746-5754

32. Jan YJ, Ko BS, Hsu C, Chang TC, Chen SC, Wang J, Liou JY: Overexpressed focal adhesion kinase predicts a higher incidence of extrahepatic metastasis and worse survival in hepatocellular carcinoma. Hum Pathol 2009, 40:1384-1390

33. Ko BS, Chang TC, Hsu C, Chen YC, Shen TL, Chen SC, Wang J, Wu KK, Jan YJ, Liou JY: Overexpression of 14-3-3epsilon predicts tumor metastasis and poor survival in hepatocellular carcinoma. Histopathology 2011, 58:705-711

34. Ko BS, Lai IR, Chang TC, Liu TA, Chen SC, Wang J, Jan YJ, Liou JY: Involvement of 14-3-3gamma overexpression in extrahepatic metastasis of hepatocellular carcinoma. Hum Pathol 2011, 42:129-135

35. Buchanan FG, Gorden DL, Matta P, Shi Q, Matrisian LM, DuBois RN: Role of beta-arrestin 1 in the metastatic progression of colorectal cancer. Proc Natl Acad Sci U S A 2006, 103:1492-1497

36. Guo HB, Lee I, Kamar M, Akiyama SK, Pierce M: Aberrant N-glycosylation of beta1 integrin causes reduced alpha5beta1 integrin clustering and stimulates cell migration. Cancer Res 2002, 62:6837-6845

37. Hohla F, Schally AV, Kanashiro CA, Buchholz S, Baker B, Kannadka C, Moder A, Aigner E, Datz C, Halmos G: Growth inhibition of nonsmall-cell lung carcinoma by BN/GRP antagonist is linked with suppression of K-Ras, COX-2, and pAkt. Proc Natl Acad Sci U S A 2007, 104:18671-18676

38. Kidd M, Modlin IM, Pfragner R, Eick GN, Champaneria MC, Chan AK, Camp RL, Mane SM: Small bowel carcinoid (enterochromaffin cell) neoplasia exhibits transforming growth factor-beta1-mediated regulatory abnormalities including up-regulation of C-Myc and MTA1. Cancer 2007, 109:2420-2431

39. Nowacki S, Skowron M, Oberthuer A, Fagin A, Voth H, Brors B, Westermann F, Eggert A, Hero B, Berthold F, Fischer M: Expression of the tumour suppressor gene CADM1 is associated with favourable outcome and inhibits cell survival in neuroblastoma. Oncogene 2008, 27:3329-3338

40. Santra M, Zhang X, Santra S, Jiang F, Chopp M: Ectopic doublecortin gene expression suppresses the malignant phenotype in glioblastoma cells. Cancer Res 2006, 66:11726-11735

41. Chang CM, Lo CH, Shih YM, Chen Y, Wu PY, Tsuneyama K, Roffler $\mathrm{SR}$, Tao MH: Treatment of hepatocellular carcinoma with adeno- associated virus encoding interleukin-15 superagonist. Hum Gene Ther 2010, 21:611-621

42. Ou DL, Shen YC, Liang JD, Liou JY, Yu SL, Fan HH, Wang DS, Lu YS, Hsu C, Cheng AL: Induction of Bim expression contributes to the antitumor synergy between sorafenib and mitogen-activated protein kinase/extracellular signal-regulated kinase kinase inhibitor $\mathrm{Cl}-1040$ in hepatocellular carcinoma. Clin Cancer Res 2009, 15:5820-5828

43. Fantl WJ, Muslin AJ, Kikuchi A, Martin JA, MacNicol AM, Gross RW, Williams LT: Activation of Raf-1 by 14-3-3 proteins. Nature 1994, 371:612-614

44. Li S, Janosch P, Tanji M, Rosenfeld GC, Waymire JC, Mischak H, Kolch W, Sedivy JM: Regulation of Raf-1 kinase activity by the 14-3-3 family of proteins. EMBO J 1995, 14:685-696

45. Komiya Y, Kurabe N, Katagiri K, Ogawa M, Sugiyama A, Kawasaki Y, Tashiro F: A novel binding factor of 14-3-3beta functions as a transcriptional repressor and promotes anchorage-independent growth, tumorigenicity, and metastasis. J Biol Chem 2008, 283:18753-18764

46. Li Y, Inoki K, Yeung R, Guan KL: Regulation of TSC2 by 14-3-3 binding. J Biol Chem 2002, 277:44593-44596

47. Shumway SD, Li Y, Xiong Y: 14-3-3beta binds to and negatively regulates the tuberous sclerosis complex 2 (TSC2) tumor suppressor gene product, tuberin. J Biol Chem 2003, 278:2089-2092

48. Han DC, Rodriguez LG, Guan JL: Identification of a novel interaction between integrin beta1 and 14-3-3beta. Oncogene 2001, 20: 346-357

49. Rodriguez LG, Guan JL: 14-3-3 regulation of cell spreading and migration requires a functional amphipathic groove. J Cell Physio 2005, 202:285-294

50. Somanath PR, Byzova TV: 14-3-3beta-Rac1-p21 activated kinase signaling regulates Akt1-mediated cytoskeletal organization, lamellipodia formation and fibronectin matrix assembly. J Cell Physiol 2009, 218:394-404

51. Liou JY, Lee S, Ghelani D, Matijevic-Aleksic N, Wu KK: Protection of endothelial survival by peroxisome proliferator-activated receptordelta mediated 14-3-3 upregulation. Arterioscler Thromb Vasc Biol 2006, 26:1481-1487

52. Liou JY, Wu CC, Chen BR, Yen LB, Wu KK: Nonsteroidal anti-inflammatory drugs induced endothelial apoptosis by perturbing peroxisome proliferator-activated receptor-delta transcriptional pathway. Mol Pharmacol 2008, 74:1399-1406

53. Porter GW, Khuri FR, Fu H: Dynamic 14-3-3/client protein interactions integrate survival and apoptotic pathways. Semin Cancer Biol 2006, 16:193-202

54. Liou JY, Ghelani D, Yeh S, Wu KK: Non-steroidal anti-inflammation drugs induce colorectal cancer cell apoptosis by suppressing 14-33e. Cancer Res 2007, 67:3185-3191

55. Hong $Y$, Jang SW, Ye K: The N-terminal fragment from caspasecleaved serine/arginine protein-specific kinase2 (SRPK2) translocates into the nucleus and promotes apoptosis. J Biol Chem 2011, 286:777-786

56. Lin HK, Wang G, Chen Z, Teruya-Feldstein J, Liu Y, Chan CH, Yang WL, Erdjument-Bromage H, Nakayama KI, Nimer S, Tempst P, Pandolfi PP: Phosphorylation-dependent regulation of cytosolic localization and oncogenic function of Skp2 by Akt/PKB. Nat Cell Biol 2009, $11: 420-432$ 